administration and the possible formation of decomposition products during prolonged boiling with fruit extracts, before the general use of thiourea as a protector of vitamin C in large-scale industrial work can be advocated; but it appears most promising of all compounds tested. Boiled vegetable extracts display a similar power of protection, which in some preparations is so complete as ta suggest the presence of specific stabilizers of possibly the thiol class. Cabbage, for example, contained an unidentified volatile thiol compound and potato juice yielded an active distillate on boiling.

\section{EFFECT OF DRINKING SMALL QUANTITIES OF SEA WATER}

$\mathrm{D}$ R. W. S. S. LADELL, of the National Hospital, Queen Square, London, has studied the effects of drinking small quantities of sea water (The Lancet, Oct. 9,1943, p. 441). The work was done for the Medical Research Council's Committee on the care of shipwrecked personnel (M.R.C. War Memo. No. 8, which does not recommend the drinking of sea water). A full report of Dr. Ladell's work will be issued later.

A man requires 800-1,000 c.c. of water a day. With less than this he contracts a water debt to his tissues. With a water debt he continues to produce only 350450 c.c. of urine a day (instead of the normal 1 litre or so), whether the water debt is large or small. During this low urinary output, the urea concentration in the urine rose to as much as 6 per cent; but the total urea output was inadequate and there was nitrogen retention with a rise of blood urea. At the same time, the salt losses in the urine were high on the first day, but they fell in a day or two to a low level. The diet of each subject of all the experiments was 'shipwreck diet' of $1 \mathrm{oz}$. daily of biscuits, sweetened condensed milk, butter fat or margarine, and chocolate. This provided not more than $1 \mathrm{gm}$. of sodium chloride daily, but more than this was excreted, so that, when no sea water or saline was drunk, there was always a slight negative salt balance. There was a definite psychological value in having an extra volume of fluid to drink (water supplemented with 3.5 per cent sodium chloride solution or with sea water), even though it tasted salty.

The results, briefly stated, were that the effects of drinking up to 400 c.c. of sea water a day, when the subjects were either totally or partially deprived of fresh water, were, on the low-calorie and low-salt diet provided, an increase in the output of urine, with an improved total urea clearance; a slight gain to the body of water, because the extra water lost in the urine is less than the extra water taken in as sea water ; and an initial retention of chloride equal to the chloride lost before the subjects began to drink sea water and, after this, a full excretion of all the chloride ingested. This restoration of the total sodium chloride content of the body may have been a manifestation of the body's tendency, indicated by the work of others whose work is quoted, to conserve its extracellular, at the expense of its intracellular, fluid.

Readers interested in the medical problems presented by the survivors of shipwrecks will find useful Surgeon-Captain Critchley's book, "Shipwreck Survivors, a Medical Study" (J. and A. Churchill, London, 1943, 7s. 6d. net).

\section{FORTHCOMING EVENTS}

(Meetings marked with an asterisk * are open to the public)

\section{Saturday, March 25}

Assoctation for Scientific Photography (at the Caxton Hall Westminster, London, S.W.1), at 2.30 p.m.- "The Assessment of Lens Performance" (Mr. A. Cox: "General Theory of Lens Performance"; Mr. H. W. Martin: "Lens Types and their Characteristics"). BIOCHEMrCar SocIETY (at the Courtauld Institute of Biochemistry Middlesex Hospital, London, W.1), at 2.30 p.m.-Annual General Meeting.

Monday, March 27

Royal Societr of ARTs (at John Adam Street, Adelphi, London, W.C.2), at 1.45 p.m.-Dr. Franklin Kidd: "Dehydration of Foodstuffs" (Cantor Lectures, 2).

Tuesday, March 28

Institute of FUed (joint meeting with the British CoAl UtilizaTION RESEARCH ASSOCIATION) (at the Institution of Electrical Engineers, Savoy Place, Victoria Embankment, London, W.C.2), at 10.30 a.m.-Symposium on "Underfeed Stokers as applied to Furnaces".

INSTITUTION OF BRITISH AgRicultoral ENGINERRs (at the Royal Society of Arts, John Adam Street, Adelphi, London, W.C.2), at 1.45 p.m.-Mr. F. A. Secrett: "Mechanisation in Market Gardening" ROYAL COLLEGe of SURGEONS OF ENGLAND (at Lincoln's Inn Fields, london, W.C.2), at 4 p.m.-Prof. Arnold Sorsby: "Blindness in Childhood; Past Achievements and Present Problems".

RoYaL InstrTution (at 21 Albemarle Street, London, W.1), at 5.15 p.m.- Sir Henry Dale, G.B.E., Pres.R.S.: "Chemical Factors in Nervous Effects", 2: "The Appearances of Two of these SubINSTITUTION OF ELECTRICAL ENGINEERS (TRANSMISSION SECTION) (at Savoy Place, Victoria Embankment, London, W.C.2), at 5.30 p.m. -Discussion on the Supply and Distribution Sections, of the Report on "Electricity Supply, Distribution and Installation" prepared by Sub-Committee No. 3 of the Post-War Planning Committee (to be opened by Mr. P. E. Rycroft).

RoYal Photographic Sochetr (ScIentific and TECHNICAI GrodP) (at 16 Princes Gate, South Kensington, London, S.W.7), at 6 p.m.Annual General Meeting. Mr. F. W. Coppin: "Production of Photographic Templates". Shefritid Metaldorgicat Assocratron (at 198 West Street,
Sheffield), at 6.30 p.m.-Mr. J. H. G. Monypenny: "The Sigma Sheffield), at 6.30 p.m.-M
Phase and its Significance".

\section{Wednesday, March 29}

Institution of Nayal ARohiteors (at the Royal Society of Arts, John Adam Street, Adelphi, London, W.C.2), at 12 noon-Annual General Meeting.

ROYAL SOCIETY of ARTS (at John Adam Street, Adelphi, London W.C.2), at 1.45 p.m.-Mr. E. R. Hamilton: "Education To-day and To-morrow", 7 : "The Training of the Teacher".

\section{Thursday, March 30}

Town and Codntry Planning Association (at 1 Grosvenor Place London, S.W.1), at 1.15 p.m.-Rt. Hon. Earl De La Warr : "National Planning Policy in relation to Agriculture". RoYal INstirumon (at 21 Albemarle Street, London, W.1), at
2.30 p.m.-Mrs. Kathleen Lonsdale: "Diamonds-Natural and Artificial"'.

ROYAL COLLEGE OF SURGEONS OF ENGLAND (at Lincoln's Inn Fields, London, W.C.2), at 4 p.m.- Prof. Arnold Sorsby : "The Sulphonamides in Ophthalmology; their Use and Limitations".

INSTITUTION OF EleCTRICAI ENGINEERS (at Savoy Place, Victoria Embankment, London, W.C.2), at 5.30 p.m.-Mr. J. A. Harle and Mr. R. W. Wild : "Restriking-Voltage as a Factor in the Performance, Rating and Selection of Circuit-Breakers"; Mr. H. E. Cox and Mr. of High-Voltage Air-Blast Circuit-Breakers".

INSTITUTION OF ELECTRICAL ENGINEERS (CAMBRIDGE AND DISTRICT INSTITUTION OF ELECTRICAL ENGINEERS (CAMBRIDGE AND DISTRICT
WIRELESS GROUP) (at the University Engineering Department WIRELESS GROUP) (at the University Engineering Department,
Trumpington Street, Cambridge), at 8.15 p.m.-Mr. R. H. Angus : "Trumpington Street, Cambridge), at

\section{Friday, March 31}

OIL aNd Colour Chemists' Association (Manchester Section) (at the Engineer's Club, Albert Square, Manchester), at 2 p.m.Mr. W. A. Silvester: "Patents at Home and Abroad".

ROYAL INSTITUTION (at 21 Albemarle Street, London, W.1), at 5 p.m.-Mr. Stanley Unwin: "Publishing in War and Peace".

\section{Saturday, April I}

BRITISH Association of ChEMISTS (LONDON SECTION) (at the Chemical Society, Burlington House, Piccadilly, London, W.1), at Community",

Thursday, March 30-Tuesday, April 4

BRimish Psychologicax Socifery (at the Training Centre, Jordanhill, Glasgow, W.3).-.-Annual General Meeting. 